\title{
Improving Health Workforce Governance: the Role of Multi-Stakeholder Coordination Mechanisms and Human Resources for Health Units in Ministries of Health
}

\section{Tim Martineau}

Liverpool School of Tropical Medicine

\section{Kim Ozano}

Liverpool School of Tropical Medicine Joanna Raven

Liverpool School of Tropical Medicine

Wesam Mansour ( $\nabla$ wesamatif@hotmail.com )

Liverpool School of Tropical Medicine https://orcid.org/0000-0002-8146-5381

\section{Fiona Bay}

Friends of Waldorf Education

\section{Dominic Nkhoma}

University of Malawi

\section{Elsheikh Badr}

Arab Board of Health Specializations

\section{Sushil Baral}

HERD International

\section{Shophika Regmi}

HERD International

\section{Margaret Caffery}

Liverpool School of Tropical Medicine

\section{Research}

Keywords: Human resources for health $(\mathrm{HRH}), \mathrm{HRH}$ governance, health workforce, coordination mechanisms, $\mathrm{HRH}$ unit

Posted Date: January 20th, 2022

DOI: https://doi.org/10.21203/rs.3.rs-1199054/v1 
License: (c) (i) This work is licensed under a Creative Commons Attribution 4.0 International License. Read Full License 


\section{Abstract}

\section{Background:}

A cohesive and strategic governance approach is needed to improve the health workforce (HW). To achieve this, the WHO Global Strategy on Human Resources for Health(HRH)promotesmechanisms to coordinate HRHstakeholders, HRH structures and capacity within the health sector to support the development and implementation of a comprehensive HW agenda and regular reportingthrough WHO's National Health Workforce Accounts (NHWA)

\section{Methods:}

Using an adapted HRH governance framework for guidance and analysis we explored the existence and operation of HRH coordination mechanisms and HRH structures in Malawi, Nepal, Sudan andadditionally from a global perspective through 28 key informant interviews and a reviewof 165 documents.

\section{Results:}

A unified approach is needed to coordination of stakeholders who support the timely development and oversight of an appropriate HRH strategy subsequently implemented and monitored by an HRH unit. Multiple HRH stakeholder coordination mechanisms co-exist, but the broader, embeddedmechanisms seemed more likely to support and sustain a comprehensive HW agenda.Including all stakeholders is challenging and the private sector and civil society were noted for their absence.The credibility of coordination mechanisms increases participation. Factors contributing to credibility included:high level leadership, organisational support and the generation and availability of timely HRH data and clear ownership by the ministry of health.

$\mathrm{HRH}$ units were identified in two study countries and were reported to exist in many countries but were not necessarily functional. There is a lack of specialist knowledge needed for the planning and management of the HWamongst staff in HRH unitsor equivalent structures, coupled with high turnover in many countries. Donor support has helped with provision of technical expertise and HRH data systems, though the benefits may not besustained.

\section{Conclusion:}

While is it important to monitor the existence of HRH coordination mechanisms and HRH structure through the NHWA, improved 'HRH literacy' for both stakeholders and operational HRH staff anda deeper understanding of the operation of these functions is needed tostrengthen their contribution to HW governance and ultimately, wider health goals.

\section{Background}


Tackling key systemic health workforce (HW)issues (quantitative shortage, skills-mix, distributionimbalance, and more) requires a cohesive and strategic governance approach centred around coordinating and implementing policies to gain improvements in workforce performance[1]. From 2006 the Global Health Workforce Alliance (GHWA) and WHO provided catalytic support to national Human Resources for Health (HRH) coordination mechanisms to ensure integrated actions[2]. In 2016, the World Health Assembly adopted the WHO Global Strategy on Human Resources for Health: Workforce 2030 [3], which established periodic reporting requirements for Member States, facilitated by WHO. Objective 3 of this Global Strategy on HRH (Build the capacity of institutions at subnational, national, regional and global levels for effectivepublicpolicy stewardship leadership and governance of actions on HRH) has two milestones that relate tocountries having "inclusive institutional mechanisms in place to coordinate an intersectoral health workforce agenda" (Milestone3.1) and having HRH Units or departments "with responsibility to developand monitor policies and plans" (Milestone3.2) - see Table 1. TheNational Health Workforce Accounts (NHWA)[4] monitor the availability of these mechanisms and structures However, a deeper understanding is needed of the governance, functions, attributes and performance of HRH stakeholder coordination mechanisms and HRH Unitsin their ability to support the "implementation of a comprehensive HW agenda in countries"[3, para55].

\section{Table 1: Definitions of HRH governance mechanisms based on the Global Strategy and NHWA [3, 4]}

\section{Term Definition}

$\mathrm{HRH} \quad$ Institutional mechanism which includes all key stakeholders and coordinates an coordination intersectoral HW agenda. Mechanisms may be a national coordination committee mechanism involving, for example, inter-ministerial Sustainable Development Goals committees, sector skills councils or similar high-level bodies with a leadership function for coordinating, developing and monitoring policies and plans on $\mathrm{HW}$, and negotiating intersectoral relationships with other line ministries, government agencies and other stakeholders.

$\mathrm{HRH}$ unit or An organisational structurereporting to a senior level within the Ministryof Health department (Director General or Permanent Secretary) with the capacity, responsibility,financing and accountability for corefunctions of HRH policy, planning and governance, datamanagement and reporting.

\subsection{Health workforce (HW) development and governance}

HW development is a technical process requiring expertise in planning, education and management, and the capacity for strategic HRH long-term planning "rooted in a long-term vision for the health system" [3, para55]. It is also a political process "requiring the will and the capacity to coordinate efforts on the part of different sectors and constituencies in society and different levels of government"[5, p798].

Governance includes rules (both formal and informal), roles and responsibilities for collective action and decision making in a system with diverse stakeholders [6, 7]. Key challenges to intersectoral governance and coordination efforts among stakeholders are willingness, commitment, technical capacity, financial mobilization, operational accountability and effective leadership [3]. 
1.2 Stakeholders in HW development and governance

A large number of stakeholders with differing - and sometimes opposing - interests occupy the 'HRH policy space' [8]which all require coordinating for HW development- see Table 2[9, p115].

Table 2: Stakeholders impacting on HRH policy

\begin{tabular}{|l|l|}
\hline Stakeholder group & Institutions \\
\hline Government & Health (national, regional, local government) \\
& Executive leadership (president, prime minister, cabinet) \\
& Legislative bodies \\
& Finance \\
& Education \\
& Labour \\
& Defence and military \\
& Civil service agencies and commissions \\
& Statutory professional councils \\
& Private for-profit businesses \\
& Public-private partnership \\
\hline Employers & Voluntary or non-profit-making organizations \\
\hline Representatives of health workers & Professional and occupational associations \\
\hline Professional and occupational unions \\
\hline International stakeholders & Bilateral and multi-lateral agencies \\
\hline Philanthropic organizations & Professional and occupational organizations \\
\hline Community based organizations \\
Patients' rights organizations \\
\hline Media \\
Pharmaceutical and medical device companies \\
\hline
\end{tabular}

There is a distinct gap in the literature surrounding both the concept and function of health workforce governance across different contexts in terms of HRH coordination mechanisms and HRH units or departments. Two studies based on surveys in Africa[10] and South East Asia[11] provide information on $\mathrm{HRH}$ units, but lack detail on how they operate. Cometto et al call for more understanding of the political 
economy of HRH policy-making and "the characteristics and performance factors, gained through the specific lens and focus on HRH units"[12, p2]. Therefore, the focus of this paper is on the functions, attributes and performance of the coordination mechanisms and HRH units. This is based on a study to review the situation globally and within three countries: Sudan, Nepal and Malawi.

\section{Methods}

\subsection{Theoretical framing of the study}

The Barbazza and Tello framework [13], adapted by Lim and Lin[1] for review of HRH governance, provides a comprehensive framework for reviewing coordination mechanisms and HRH units. In this study, we have adapted and expanded the Barbazza and Tello frameworkand have added the dimensions of 'ownership' from Buse and Walt[14]and 'HRH literacy' from Martiniuk[15]in Table 3 below.

Table 3: Dimensions of HRH governance framework for reviewing the HRH coordination mechanisms and HRH units

\begin{tabular}{|l|}
\hline Dimensions of Governance \\
\hline Accountability \\
\hline Leadership \\
\hline Partnership \\
\hline Ownership \\
\hline Formulating policy/strategic direction \\
\hline Generating information/intelligence \\
\hline Organizational adequacy/system design \\
\hline Participation and consensus \\
\hline Sustainability \\
\hline HRHperformance \\
\hline HRH literacy \\
\hline
\end{tabular}

\subsection{Study design}

We used a rapid qualitative study design to address the research aim. We employed two methods: document review and in-depth interviews with a small number of selected informants (both global and specific to each of the three countries). Both methods were guided by the HRH governance framework described above. 


\subsection{Study sites}

Three countries, namely Malawi, Nepal and Sudan, part of the WHO regions of AFRO, SEARO andEMRO, respectively, were selected for the study. These countries signed up to the Kampala Declaration and Agenda for Global Action in 2008 commitments [16] and were supported by the Global Health Workforce Alliance programme [2]. They are on the WHO's health workforce support and safeguard list because of staff shortages [17], and HRH functions are partially decentralised. The research team has existing linkswith these countries which enabled rapid data collection. Table 4 provides information about each country.

Table 4: Country contexts 


\begin{tabular}{|c|c|c|c|}
\hline & Malawi & Nepal & Sudan \\
\hline Population & $\begin{array}{l}18.63 \text { million } \\
(2019) \S\end{array}$ & 28.60 million (2019)§ & 42.81 million (2019)§ \\
\hline $\begin{array}{l}\text { Total Health } \\
\text { workforce[1] }\end{array}$ & $37,926 \S$ & $54,177 \S$ & $150,000 \S$ \\
\hline \multicolumn{4}{|l|}{$\begin{array}{l}\text { Per } 10,000 \\
\text { population }\end{array}$} \\
\hline Doctors & $0.36(2018) \S$ & $8.09(2010) \S$ & $2.62(2017) \S$ \\
\hline $\begin{array}{l}\text { Nursing } \\
\text { Personnel }\end{array}$ & $4.39(2018) \S$ & $21.25(2019) \S$ & $11.45(2018) \S$ \\
\hline $\begin{array}{l}\text { Midwifery } \\
\text { Personnel }\end{array}$ & $0.33(2016) \S$ & $\mathrm{N} / \mathrm{A}$ & $\mathrm{N} / \mathrm{A}$ \\
\hline Dentists & $0.02(2018) \S$ & $1.12(2019) \S$ & $2.09(2015) \S$ \\
\hline Pharmacists & $0.06(2018) \S$ & $1.35(2019) \S$ & $0.25(2017) \S$ \\
\hline $\begin{array}{l}\text { Total stock } \\
\text { of above } \\
\text { cadres }\end{array}$ & 1349 (2018) & $63,944(2019)$ & $35,964(2017) \S$ \\
\hline \multirow{2}{*}{$\begin{array}{l}\mathrm{HRH} \\
\text { strategy }\end{array}$} & $2012-2016$ & $2012-2016$ & $2012-2016$ \\
\hline & 2018 - 2022 (in use) & 2020-2030 (approved) & $\begin{array}{l}2018 \text { strategy (in } \\
\text { progress) }\end{array}$ \\
\hline \multirow[t]{4}{*}{$\begin{array}{l}\text { Health } \\
\text { service } \\
\text { providers }\end{array}$} & \multirow{2}{*}{$\begin{array}{l}\text { Ministry of } \\
\text { Health }(\mathrm{MoH})- \\
69 \% \text { * }\end{array}$} & $\begin{array}{l}\text { Ministry of Health and population - } \\
67 \%\end{array}$ & $\begin{array}{l}\text { By funding \#: } \\
\text { Public sector - }\end{array}$ \\
\hline & & Private healthcare providers $-26 \%$ & $23.28 \%$ \\
\hline & $\begin{array}{l}\text { Association of } \\
\text { Malawi }-29 \% \text { * }\end{array}$ & \multirow[t]{2}{*}{$\begin{array}{l}\text { Non-Governmental } \\
\text { Organisations/Faith Based } \\
\text { Organisations/others - } 3 \%\end{array}$} & $\begin{array}{l}\text { Private sector - } \\
70.30 \%\end{array}$ \\
\hline & $\begin{array}{l}\text { Private sector } \\
\text { providers }-2 \% \text { * }\end{array}$ & & Other $-6.42 \%$ \\
\hline $\begin{array}{l}\text { Form of } \\
\text { Decentralis- } \\
\text { ation }\end{array}$ & $\begin{array}{l}\text { Decentralised to } \\
\text { district level }\end{array}$ & $\begin{array}{l}\text { Federalisation and decentralised to } \\
\text { local government/municipality }\end{array}$ & $\begin{array}{l}\text { Devolution to State } \\
\text { level (18 States) }\end{array}$ \\
\hline
\end{tabular}

Data sources:§ = National health Workforce Accounts [18]* = Malawi HRH strategy 2018[19] \# =System of health accounts report [Sudan][20]

\subsection{Document review}

The review examined the normative guidance on the areas of a) HRH stakeholder coordination and b) management through HRH units (or equivalent structures) within a governance framework globally as 
well as in the three study countries.

At global level, we searched for: journal articles through Medline and Google Scholar and for policy documents from organisations and websites from 2004 - the start of major HRH strengthening interventions with the launch of the 'Joint Learning Initiative (JLI) report'[21].

At country level we searched for relevant journal articles through Medline and Google Scholar and for policy documents. We followed up references of relevant documents and on advice of key informants. Table 5 provides details on the numbers and types of documents reviewed.

We screened each title and abstract and where it was identified as being relevant, we read the full document and included it in the final analysis. We identified 165 documents as shown in Table 5 below.

Table 5: Number and type of documents reviewed

\begin{tabular}{|c|c|c|}
\hline Location & $\begin{array}{l}\text { No. of } \\
\text { documents } \\
\text { reviewed }\end{array}$ & Type of documents reviewed \\
\hline Global & 95 & $\begin{array}{l}\text { Journal articles; documents from WHO HQ and regional offices,the Global } \\
\text { Health Workforce Network and its predecessor the Global Health Workforce } \\
\text { Alliance, regional HRH organisations such as the Asia Pacific Action } \\
\text { Alliance on Human Resources for Health (AAAH), contemporary global } \\
\text { HRH projects such as CapacityPlus and HRH2030; websites of } \\
\text { international organisations (such as WHO and the World Bank) }\end{array}$ \\
\hline Malawi & 19 & \multirow{3}{*}{$\begin{array}{l}\text { Relevant journal publications; current and recent HRH policies, strategies } \\
\text { and reviews; wider contemporary policies, strategies and reviews on HRH } \\
\text { and other factors impacting on HRH governance, coordination and } \\
\text { leadership and management such as budget reform, civil service reform } \\
\text { and decentralisation; HRH project reports; websites of international } \\
\text { organisations (such as WHO and the World Bank), those working in the } \\
\text { health workforce field and ministries of health, professional bodies and } \\
\text { development partners in each of the study countries. }\end{array}$} \\
\hline Nepal & 33 & \\
\hline Sudan & 18 & \\
\hline Total & 165 & \\
\hline
\end{tabular}

\subsection{Key informant interviews}

Using country and respondent-tailored topic guides, interviews carried out between July and September 2021 exploredthe functions of HRH Coordination Mechanisms and HRH Units, key attributes related to $\mathrm{HRH}$ governance, including participation, accountability, organisational adequacy, sustainability, and $\mathrm{HRH}$ performance/outcomes. The key informants were purposively selected based on: their experience of working or advising at strategic level on HRH coordination, leadership and management in the government health sector; knowledge of contemporary HRH situation at national and sub-national levels including policies, systems and practices. This enabled a mix of perspectives which supported our approach of triangulation. 
Table 6 provides an overview of the key informants. The research team conducted the interviews virtually via Zoom or TEAMS, in English and they lasted between 60 and 90 minutes. They were recorded following consent of the participants.

Table 6: Overview of key informants

\begin{tabular}{|llc|}
\hline $\begin{array}{l}\text { Study } \\
\text { site }\end{array}$ & Key informants & $\begin{array}{c}\text { Number } \\
\text { (female) }\end{array}$ \\
\hline $\begin{array}{l}\text { Global } \\
\text { (GLO) }\end{array}$ & $\begin{array}{l}\text { HRH experts at global or regional level working in international organisations } \\
\text { or as consultants }\end{array}$ & $7(2)$ \\
\hline $\begin{array}{l}\text { Malawi } \\
\text { (MWI) }\end{array}$ & $\begin{array}{l}\text { National HRH stakeholders, including government officials at national and sub- } \\
\text { national levels, development partners/donors, regulatory bodies, UN agencies }\end{array}$ & $6(0)$ \\
\hline $\begin{array}{l}\text { Nepal } \\
\text { (NPL) }\end{array}$ & & $6(1)$ \\
\hline $\begin{array}{l}\text { Sudan } \\
\text { (SDN) }\end{array}$ & & $8(5)$ \\
\hline $\begin{array}{l}\text { Grand } \\
\text { total }\end{array}$ & - & $\mathbf{2 7}(\mathbf{8})$ \\
\hline
\end{tabular}

\subsection{Data management and analysis}

We transcribed verbatim the recordings of the interviews. For data anonymisation, we provided a sited code (see Table 6) and serial number for each transcript e.g. (GLO 001, SDN 004). We used the thematic framework approach to analyse the interview and document review data, supported by NVIVO programme [22]. We developed a coding framework for all settings from the topic guides, research objectives and themes emerging from reading the transcripts and desk review information whilst being informed by dimensions of the HRH governance framework. We applied the framework to the transcripts and data and developed charts for each code. We then identified and agreed key themes.

\section{Results}

\subsection{HRH coordination mechanisms}

This section reports on the coordination mechanisms, their main functions and selected attributes (particularly the wider coordination mechanisms) including leadership and accountability; participation, inclusivity and consensus building; sustainability; and finally, performance.

\subsubsection{Coordination mechanisms}


Multiple coordination mechanisms were identified in all three study countries (see Table 7). Malawi's HRH TWG and Sudan's National Stakeholder Forum have broad stakeholder reach and appeared to be long standing and embedded in the MoH systems. Nepal does not have a fully institutionalised health workforce stakeholder coordination mechanism. However, it has general coordination mechanisms that include health workforce and has ad hoc task-focused mechanisms such as the HRH roadmap working group.

Table 7: Summary of coordination mechanisms and functions in study countries. 


\begin{tabular}{|c|c|c|}
\hline Country & Type of Mechanism & Summary of functions \\
\hline \multirow[t]{3}{*}{ Malawi } & $\begin{array}{l}\text { Health Sector Working } \\
\text { Group, MoH }\end{array}$ & $\begin{array}{l}\text { Oversees all MoH Technical Working Groups (TWGs), } \\
\text { including HRH TWG }\end{array}$ \\
\hline & & $\begin{array}{l}\text { The ultimate governance body for the health sector, the } \\
\text { highest level governance body that can tackle HR issues when } \\
\text { necessary (MWI 003) }\end{array}$ \\
\hline & & $\begin{array}{l}\text { Comprisesthe Secretary for Health, donors, civil society, the } \\
\text { private sector, other government departments, but attendance of } \\
\text { other Ministries, this also is something that's not really very } \\
\text { strong (MWI 003) }\end{array}$ \\
\hline
\end{tabular}

HRH TWG, under the Health Sector Working Group, $\mathrm{MoH}$
Multisectoral and multi-partner mechanism, established in the early 2000s; comprises approx. 30 members (covering multiple central government departments, local government, regulatory bodies, training institutions, the faith-based organisations, development partners and donors, some of whom provide technical and financial support to $\mathrm{HRH}$ functions)

Provides technical advice and generates evidence for $\mathrm{MoH}$ Senior Management TeamHRH decision making; reviews and endorses national HR policies and plans $[19, \mathrm{p} 23]$

Monitors and reviews implementation of HRH Strategic Plan against annual targets and planned activities $[19, \mathrm{p} 17]$

Advocates for adequate funding [19, p23]

Functions according to TOR, led by the MoH HR Director (Chair), with a development partner as rotational co-Chair, withMoH Directorate of Human Resource Management and Development (DHRMD) providing the Secretariat

Meets quarterly

Athink tank that considers issues government cannot make a decision about (MW 001)
Task Forces, under the HRH TWG, MoH
- $\quad$ Constituted by the HRH TWG to work on specific HRH issues and tasks as per agreed ToR e.g. the development of the HRH strategy, recruitment

- $\quad$ Comprises volunteer TWG members and consultant hired when required

Mechanism through which the TWGs deliver (MWI 001)

Parliamentary Committee for Health

Permanent Secretaries (PS) Committee
Advocates for health including health workforce issues

Multi sectoral committee addressing health sector issues, includes Permanent Secretary for Health and for DHRMD in the Office of the President and Cabinet. among others

Health sector coordination and policy decision making, and potential to influence $\mathrm{HRH}$ decision making 


\begin{tabular}{|c|c|c|}
\hline \multirow[t]{4}{*}{ Country } & Type of Mechanism & Summary of functions \\
\hline & $\begin{array}{l}\text { MoH Senior } \\
\text { Management Team }\end{array}$ & $\begin{array}{l}\quad \text { Main decision-making body in the MoH, considers } \\
\text { evidence presented by all TWGs, including HRH TWG for HRH } \\
\text { decision making and allocating resources }\end{array}$ \\
\hline & $\begin{array}{l}\text { Human Resources for } \\
\text { Health (HRH)Coalition }\end{array}$ & $\begin{array}{l}\text { Umbrella body for professional associations and unions } \\
\text { including medical and nurses and midwives' associations }\end{array}$ \\
\hline & & $\begin{array}{l}\text { Petitions government on various } \mathrm{HRH} \text { issues on behalf of } \\
\text { its members }\end{array}$ \\
\hline \multirow[t]{8}{*}{ Sudan } & National Human & . $\quad$ Established 2007 \\
\hline & Observatory (NHRHO) & . $\quad$ Produces evidence and documents for review \\
\hline & & $\begin{array}{l}\text { Develops meeting agendas, follows up actions identified } \\
\text { by the Stakeholders Forum }\end{array}$ \\
\hline & National HRH & Multisectoral body \\
\hline & $\begin{array}{l}\text { NationalHRH } \\
\text { Stakeholder Forum } \\
\text { reporting to the }\end{array}$ & $\begin{array}{l}\quad \text { Headed by the Undersecretary for Health with links to the } \\
\text { President and has "the strength and the power and the } \\
\text { authorization even to push HRH issues and agenda" (SDN 004) }\end{array}$ \\
\hline & Healthcare & . $\quad$ Serves as the Board for the NHRHO \\
\hline & & $\begin{array}{l}\text { Coordination and decision-making role e.g. salary } \\
\text { increases, distribution, production and migration, "when the } \\
\text { decision is taken in this committee, so it is likely to be done" } \\
\text { (SDN 002) }\end{array}$ \\
\hline & & . $\quad$ Meets quarterly \\
\hline \multirow[t]{7}{*}{ Nepal } & $\begin{array}{l}\text { Health Coordination } \\
\text { Division,MoHP }\end{array}$ & $\begin{array}{l}\text { General health coordination role across the three tiers of } \\
\text { government, including for HRH }\end{array}$ \\
\hline & & $\begin{array}{l}\text { Coordination with multisector including development } \\
\text { partners }\end{array}$ \\
\hline & $\begin{array}{l}\text { Ad hoc } \\
\text { TWGs/committees, }\end{array}$ & $\begin{array}{l}\text { CCF process todevelop } 2011 \mathrm{HRH} \text { plan which included } \\
\text { task-specific working groups }\end{array}$ \\
\hline & specific tasks) & $\begin{array}{l}\text { Development of the HRH Strategic Plan/Roadmap (2017- } \\
\text { 2020) co-led by MoHP and WHO }\end{array}$ \\
\hline & & $\begin{array}{l}\text { Committee for planning for the (re) deployment of staff - } \\
\text { the Employee Adjustment process - under federalisation }\end{array}$ \\
\hline & & $\begin{array}{l}\text { Groups may comprise } \mathrm{MoH} \text { officials and development } \\
\text { partners }\end{array}$ \\
\hline & $\begin{array}{l}\text { Interdivisional } \\
\text { meetings, MoHP }\end{array}$ & $\begin{array}{l}\text { Weekly meetings to discuss policy issues, including } \mathrm{HRH} \text {, } \\
\text { but "lack of clear agenda, preparation and participation"(NPL } \\
004) \text {. }\end{array}$ \\
\hline
\end{tabular}

\subsubsection{Attributes}


The important attributes of the coordination mechanismscover leadership and accountability; participation, inclusivity and consensus building; and sustainability.

\subsubsection{Leadership and accountability}

The TWG in Malawi is led by the MoH and is accountable to the broader Health Sector Working Group and the MoH Senior Management Team, "who decides whether to allocate funds to execute" (MWI 001). The National HRH Committee in Sudan is also led by the Under-secretary for Health and accountable to the President, which gives it power. The interdivisional coordination mechanisms in the MoHP in Nepal report to the Secretary in the MOHP, and the HRHRoadmap TWG was led by the joint-secretary and reported to the Secretary MoHP.

The coordination mechanisms in Sudan had clear Terms of Reference(TOR)and guidance documents which describe the roles and responsibilities of the members, the reporting system, and schedule of meetings, with the HR observatory acting as the secretariat. In Malawi, the HRH TWG and the task forces reportedly had clear TORs. There are clear procedures for MoHP interdivisional meetings in Nepal. These instruments, along with the leadership capabilities of senior management (GLO 001), enhance the legitimacy of the mechanisms.

Leadership capacity was impacted by high staff turnover in Malawi and Sudan (partly through migration). $\mathrm{HRH}$ coordination mechanisms should address national rather than donor-driven priorities (GLO 003), but because of frequent changes in leadership in the MoHP (NPL 002, NPL 003 and NPL 005) the TWG in Nepal was driven by a development partner. A participant in Malawi referring to the development of the HRH Strategy described how development partners 'jumped in', 'took the heavy lift', and how a "team of experts really pushed with the HRH Directorate, and then it came to reality (MWI 006).

\subsubsection{Participation, inclusivity and consensus building}

The Malawi TWG had wide participation (see Table 7). In Sudan, the Stakeholder Forum had a similarly wide reach of stakeholders with additional attendance by police and military HRH representatives. Respondents highlighted thechallenge of leadingand maintainingsuch large and diverse groupsengaged; this required effective communication and trust building efforts. In Nepal and Malawi, the composition of the working groups depends on the task, but donors and development partners will usually participate if they are contributing funds. In Malawi, participation by some MoH Directorates can be sporadic. At one point Sudan had dedicated staff and budgets to promote stakeholder engagement.In all three cases,some allowances were needed to support participation.

In Sudan, development partners, including UN agencies, have their own forum for general coordination which is represented in the NHC. In Malawi, development partners are members of the TWG, and one is 
always the co-chair. In Nepal the composition of the working groups depends on the function, but development partners contributing funds usually participate.

Though there is rapid expansion of private health worker training in Nepal and Sudan. The for-profit private (health) sector, which lack representative bodies, was absent from the HRHcoordination mechanisms. Moreover, in Sudan, the private (health) sectorremains unconvinced of the value in sharing data or the benefits of participation. Civil society was also missing from HRH coordination in thestudy countries.

Tensions and conflicts between stakeholders were reported due to the politicisation of health and healthcare funding and the presence of many powerful actors who believe they have a legitimate HRH governance and gatekeeping remit (GLO 002; GLO 006). These tensions were often intersectoral, such as education and defence (e.g. reluctance of security forces to share information in Sudan) or as a result of political transitions and resultant changes in institutional roles and responsibilities(GLO 001 and GLO 008). However,consensus-building,collective agenda setting,sharing objectives, use of workshops and informal communication helped to foster collective insight and views on the HRH topic, which eased tensions. Several global respondents observed that this process also improved HRH literacy amongst stakeholders and in Sudan '...the structures for coordination and the meetings, the culture of frequent meetings, has done a lot to mediate this relationship and to address conflicts." (SDN001).

\subsubsection{Sustainability}

Many respondents emphasised the need for a sustained forum for developing and overseeing the longterm strategy for the health workforce. The longevity of the HRH TWG in Malawi, despite high turnover of government staff, was attributed in part to its embeddedness within existing $\mathrm{MoH}$ governance structures and the perception by stakeholders that it was "a competent structure"and essential to the coordination of new initiatives: "a donor wouldn't really commit into a serious undertaking before being convinced that the TWG has reviewed and is happy with the direction"(MWI 005).

In contrast, the functioning of the high-profile Stakeholder Forum in Sudan was affected by the recent political transition in the country. One respondent claimed that " $i t$ [Stakeholder Forum] was functioning, though the country was unstable politically and the issues around the revolution make it a bit difficult to have the regular meetings as it is scheduled in the plan." (SDN 004).

Holding regular face-to-face meetings can be expensive if held in hotels and travel costs are required, though for smaller meetings one respondent (NPL 005) said that paying for a "few cups of tea" was a good investment if it helped bring people together. In Sudan, the Stakeholder Forum had dedicated government funding and commitment, with the majority provided through external partners and donors, though"sometimes [per diems] it's equal[...] maybe to their[...] monthly salary. So this is one of the things that really motivate people to attend" (SDN 009). During the pandemic in Malawi, the opportunity to hold virtual meetings meant more people were available, meetings were more frequent and cheaper. 


\subsubsection{Performance}

The coordinating mechanisms in Sudan and Malawi and the Road map working group in Nepal had all supported the development of HRH strategic plans to support the long-term health workforce strategy. The coordinating mechanisms in Sudan and Malawi appeared to meet regularly, though this became difficult in Sudan after the 2019revolution in Sudan. Effective HRH coordination mechanisms were reported in Indonesia under the UHC umbrella which shared information and planning processes (GLO 006); and in Mozambiquewhere a strong champion created the coordination mechanism which was supported by an HRH observatory. They gained the interest of stakeholders by demonstrating at the health system annual reviews that "even if the issue is not a workforce issue, if you bring it their attention, and workforce component will be looked at" (GLO 003). Two global respondents compared the challenge of coordinating multiple stakeholders in larger - especially federated - countries with smaller countries where all stakeholders could be "in one room" (GLO 002).

\subsection{HRH Units}

This section reports on findings about the structures of HRH Units, their functions and attributes (leadership/accountability, capacity, support to decentralised HRH units), and performance.

\subsubsection{Types and functions of HRH units}

Table 8 shows that whereas Malawi and Sudan have clear HRH units to oversee health workforce functions, in Nepal there was no single structure to provide this oversight.

\section{Table 8: Summary of HRH units}




\begin{tabular}{|c|c|c|}
\hline Country & Type of HRH Unit & Description/Function \\
\hline \multirow[t]{8}{*}{ Malawi } & \multirow{8}{*}{$\begin{array}{l}\text { Directorate of Human } \\
\text { Resource } \\
\text { Management and } \\
\text { Development } \\
\text { (DHRMD), Ministry of } \\
\text { Health (MoH) }\end{array}$} & $\begin{array}{l}\text { Provides strategic direction on the rational use of } \mathrm{HRH}[19 \text {, } \\
\mathrm{pp} 23-4]\end{array}$ \\
\hline & & $\begin{array}{l}\text { Headed by a Director who reports to the Principal } \\
\text { Secretary for Health }\end{array}$ \\
\hline & & . $\quad$ Provides the secretariat for the HRH TWG \\
\hline & & $\begin{array}{l}\text { Leads the implementation of the HRH Strategic Plan } \\
(2018-2022)\end{array}$ \\
\hline & & $\begin{array}{l}\text { Relies on external technical assistance to perform core } \\
\text { functions such as workforce planning }\end{array}$ \\
\hline & & $\begin{array}{l}\text { Comprises health workforce planning; management; and } \\
\text { development sections }\end{array}$ \\
\hline & & $\begin{array}{l}\text { The health workforce management section is responsible } \\
\text { for a broad range of HRM functions, including the } \\
\text { "interpretation of the Malawi Public Service Regulations (MPSR) } \\
\text { for central hospitals" [19] }\end{array}$ \\
\hline & & $\begin{array}{l}\text { Works with the Health Services Commission, Local } \\
\text { Government Service Commission, and District Councils which } \\
\text { have responsibility for some HR functions }\end{array}$ \\
\hline \multirow[t]{3}{*}{ Sudan } & \multirow[t]{3}{*}{$\begin{array}{l}\text { Directorate General of } \\
\text { HRH,Federal Ministry } \\
\text { of Health (FMoH) }\end{array}$} & $\begin{array}{l}\text { Evolved from personnel management unit in } 2003 \text { to a } \\
\text { Directorate General of HRH Development, reporting directly to } \\
\text { the Undersecretary for Health }\end{array}$ \\
\hline & & $\begin{array}{l}\text { Responsible for "strategic health workforce development } \\
\text { including the development of several policies for the health } \\
\text { workforce and expanding its role in coordination and facilitation } \\
\text { of the health workforce issues"(SDN001) }\end{array}$ \\
\hline & & $\begin{array}{l}\quad \text { Includes } 8 \text { directorates and institutes to carry out } \\
\text { functions with } 150 \text { staff: Policy and Planning, National HRH } \\
\text { Observatory, Internship Affairs, Fellowships Affairs, Continuous } \\
\text { Professional Development (CPD), Academy of Health Science } \\
\text { (AHS), Public Health Institute (PHI) (now under the direct } \\
\text { management of the Undersecretary of Health), Blue Nile } \\
\text { National Institute for Communicable Diseases (BNNICD) } \\
\text { managed collaboratively with the University of Gezira }\end{array}$ \\
\hline \multirow[t]{2}{*}{ Nepal } & \multirow{2}{*}{$\begin{array}{l}\text { Personnel } \\
\text { Administration } \\
\text { Section, Division of } \\
\text { Administration, } \\
\text { Ministry of Health and } \\
\text { Population (MoHP) }\end{array}$} & $\begin{array}{l}\quad \text { Covers all functions related with personnel } \\
\text { administration,HRH information, communication and } \\
\text { management }\end{array}$ \\
\hline & & $\begin{array}{l}2012 \text { Mid-Term Review of Nepal Health Sector Strategic } \\
\text { Plan NHSP-2recommended for "a single human resources } \\
\text { division and that all human resources activities are assigned to } \\
\text { this division" [24, p15]but not acted on. }\end{array}$ \\
\hline
\end{tabular}




\begin{tabular}{|c|c|c|}
\hline Country & Type of HRH Unit & Description/Function \\
\hline & $\begin{array}{l}\text { Curative Service, } \\
\text { Education, and } \\
\text { Research Section, } \\
\text { under Policy, Planning } \\
\text { and Monitoring } \\
\text { Division, MoHP }\end{array}$ & $\begin{array}{l}\text { Responsible for coordination with health academia, } \\
\text { education institutions, hospitals, and technical schools }\end{array}$ \\
\hline & $\begin{array}{l}\text { Health Coordination } \\
\text { Division, MoHP }\end{array}$ & $\begin{array}{l}\quad \text { Responsible for: the Employee Adjustment process; } \\
\text { formulation of HRH policies and plans; workforce planning and } \\
\text { projection; HR information systems; training needs assessment, } \\
\text { training plans and career development; and HRH research [41] }\end{array}$ \\
\hline & & . Includes Provincial and Local Health Coordination Section \\
\hline & & [41] \\
\hline & $\begin{array}{l}\text { AdministrationSection, } \\
\text { Department of Health } \\
\text { Services (DoHS) }\end{array}$ & $\begin{array}{l}\text { Personnel administration for staff employed by DoHS, } \\
\text { including attendance and staff leave. }\end{array}$ \\
\hline & $\begin{array}{l}\text { National Health } \\
\text { Training Centre, } \\
\text { Department of Health } \\
\text { Services (DoHS) }\end{array}$ & $\begin{array}{l}\text { Responsible for: } \mathrm{HRH} \text { training strategy and plan; } \\
\text { coordination for training and other capacity development } \\
\text { initiatives for } \mathrm{HRH} \text {; development and use of training materials } \\
\text { for HRH }\end{array}$ \\
\hline & $\begin{array}{l}\text { Nursing Capacity } \\
\text { Development Section, } \\
\text { under the Nursing and } \\
\text { Social Security } \\
\text { Division, DoHS }\end{array}$ & $\begin{array}{l}\text { Coordination of planning, capacity development and } \\
\text { management of nursing and midwifery work force }\end{array}$ \\
\hline
\end{tabular}

All 11 countries in the Southeast Asia region reported in 2019 that they have some form of health workforce unit, compared with eight in 2018[23], though in Timor-Leste "it was just a one-person show." (GLO 001). In the African region, 15 out of 16 countries surveyed: "had a responsible HR unit ... but in practice, what had happened was that it was not really functional, many of them were just passing papers in practice" (GLO 003). Below we have listed selected findings relating to the functions of the HRH units (or equivalent).

\subsubsection{HRH strategy: development and implementation}

$\mathrm{HRH}$ functions need to be coordinated within the MoH (GLO 008). A HRH strategic plan is need for both stakeholders and within the MoHto guide, coordinate, and align $\mathrm{HRH}$ initiatives to longer-term health plans. Nevertheless, thefindings showed that Malawi was the only study country with a plan (201822)currently being implemented.The development of an $\mathrm{HRH}$ plan appeared to be very time consuming, often getting stuck at the approval stage with Nepal's 2020-2030 plan only recently signed off. As a pathfinder country for GHWA, there was some externalfundingfor developing Sudan's 2012-16 HRH strategy, but the process was apparently owned by the $\mathrm{MoH}$ and national stakeholders. In contrast, according to some respondents, the development of strategic HRH strategyin Malawi and Nepalwasstrongly influencedby development partners.Implementation may be hampered without 
alignment to the budget process. Although Nepal's $2011 \mathrm{HRH}$ strategywas officially approved and aligned to the budget "the implementation of activities in the strategic plan which require financial resources [was] therefore frozen."[24, p41].Dissatisfaction with thefinancing andimplementation of Malawi's current strategy was expressed:"you need to have a proper budget, you need to have a proper plan, indicators, whether you meet those things or not, so, there should be that kind of platform" (MWI 006).

One global respondent remarked that in many countries $\mathrm{HRH}$ departments do not operate at a strategic level and are mainly focused on routine recruitment and deployment (GLO 001).Sometimes major HRH changes may be taken on by a different department. The 'employee adjustment process' to support federalisation in Nepal was not managed by HRH officials, but a focal person of the rank of Chief Specialist was appointed to manage this process (NPL 002).

\subsubsection{Workforce planning and HR information}

Though workforce planning is often a "self-contained exercise within the health sector carried out in relative isolation from other development processes"[25, p359], in Malawi the staffing projections were part of the wider strategic HRH plan. The intelligent usage of $\mathrm{HRH}$ data[26]is needed for workforce planning and other workforce management processes. WHO has supported Health workforce observatories to generate such data. In 2015, 34 member states in the AFRO region had these observatories - including Sudan [27], yet most countries struggle to get accurate, comprehensive and current data on the workforce and only nine are currently active in the African region [28]. Despite years of donor support, the dedicated HRH information system in Nepal had failed and reliance of the personnel information system (PIS) for civil servants - including health workers -is only of" some limited use for the training and other planning purposes" (NPL002). Sudan's donor support to HRH information systems was curtailed by political sanctions. In Malawi, several information systems were in place,but the outputs could not be combined to produce useful information. In Indonesia the HRH data sharing between ministries was spelled out in a memorandum of understanding "being very clear what data is going to be shared, when, by whom, and which platforms and everything ... they were very systematic on that"(GLO 006).

\subsubsection{Lessons from COVID-19 about existing functions}

A report from the South East Asian regionsuggested that lessons from COVID-19on surge management and protection of health workers should be integrated into updated national HRH strategies [29]. In Malawi, in response to the COVID-19 pandemic, recruitment processes that normally take six months were completed "within two weeks or even less than that, and that is without compromising any quality" (MWI 006).

\subsubsection{Missing HRH functions}

In Sudan the HR manual identifies the need for anemployee relations unit, and this has been recommended in Nepal[30]. However, in spite of the risk of industrial action generally [28]and in all study 
countries some of which was related to COVID-19, there was no evidence of the practice of 'employee relations' within $\mathrm{MoH}$ structures.

\subsubsection{Attributes}

Three important attributes of the HRH Unitsemerged from the findings: leadership and accountability; capacity of HR unit staff; and support to decentralised units.

\subsubsection{Leadership and Accountability}

The success of Sudan's HRH Directorate was attributed to the leadership's clear vision and ability to think "outside the box and how to conduct thingsnot like ... routine" (SDN 009).Elsewhere, HRH units may be hampered by unclear mandates and weak coordinating powers[8] or be low in the organisational hierarchy excluding them from strategic decisions-making[31].Leadership at levels above the HRH unit was also cited as being important to the creation and functioning of such a unit. Strong support was demonstrated in Sudan, but despitenumerous callsfor its establishment the Personnel Administration Section In Nepal has not been replaced by dedicated HRH Division - "this is the leadership matter"(NPL 002).Weak leadership at both levels will affect accountability. Lack of ownership where initiatives were driven externally, such as the development of strategic HRH plans, was also found to be associated with lack of accountability.

\subsubsection{Capacity of HR Unit staff}

The Global HRH strategy [3] promotes the need for a professionalised body of HRH scientists, planners and policymakers to support HRH at a strategic level. Some respondentsreported HRH expertise in selected high-income countries, but a recent study in the South-East Asia region found that only $14 \%$ of staff in the HRH units were professionals(eg with Master's Degree in Public Health)[23] and in the African region only $7 \%$ of staff were described as 'technical'[28]. In Malawi and Nepalthe HRH functions are staffed by people from "common services" ministries with knowledge of routine personneladministration, but who may be unfamiliar with the complexities of developing and managing a health workforce. "The perception is just managing, veterinarian managing, agriculture managing[....]or managing other things, the same with the public health and the public or the physicians or nurses. They look [at] everything as ... general." (NPL 006). Arespondent from Malawi observedthat generally "people who are thrown to the HR department are those who are incapable, or who has a disciplinary issue or who want to have some calm time, so that they will do their own things. So, that is the debacle and because of those things always you see capacity issues"(MWI 006).

Becoming 'literate' about the health workforce takes time. One respondent at a senior level in Sudan had been working for many years inHRH. However, just when the officer can develop effective and appropriate 
strategies, they may be transferred: "when they start to pick up things, they also move to the other institution. So that's really quite a big handicap for an institution as specialized as health."(MWI 003). A review from Nepal in 2013 showed very high turnover of staff working on HR functions, especially those in leadership roles [30]. High turnover of senior managers has continued in Nepal, some of which is associated with political instability. In Sudan, training in health workforce developmentcontributed to improved capacity of the HRH directorates at State and National levels.In the absence of a stable body of $\mathrm{HRH}$ professionals, some countries have relied on the use of international consultants with the risk that no expertise remains when the contracts finish [8]. "In Burkina[Faso] they have received support from I think Belgium cooperation to have again an expert to strengthen the HRH unit. And they have done a good job to strengthen HRH information system at the national level. And then when the expat left, nobody was able to manage the system. Then the system died." (GL 004)

\subsubsection{Support to decentralised Units}

Many countries either have or are moving towards decentralised health systems and management of the health workforce, as in the three study countries. This requires provision of support, including capacity strengthening,to the decentralised $\mathrm{HRH}$ units[3, 32].Support strategieswere included in Sudan strategic HRH plan for 2012-16 [33] and implemented. One respondent reported that all 18 state-level HRH units (staffed with one or more focal persons)are functioning. Strategies to support decentralised HRH units in the federal, provincial, municipal structures were included in Nepal's HRH Roadmap. Similar support to Malawi's devolution was anticipated in its HRH strategic plan - the "devolution of the HR function led to a delineation of roles and responsibilities between the line Ministry (MoHP) and the Councils"[19, p16], but at the time of this study, institutional HRH roles and responsibilities e.g. of the health service commission and the local government service commissionat central and subnational levels had not been fully delineated.

\subsubsection{Factors impacting on performance}

A range of factors were found to impact on the performance of HRH Units, including: their legitimacy and power linked to positioning within the $\mathrm{MoH}$ structure and hierarchy(GLO 001) [10]; their political capital and engagement of stakeholders at the highest level, "that gives you the power in order to bring different departments on the table" (GLO 001); and "funding power" (GLO002). To maintaintechnical autonomy and financial and programmatic independence, availability and use of monitoring and evaluation instruments and HR data are needed to monitor, report on and be accountable for results. This requires the availability and retention of HR literate professionals [11].

\section{Discussion}

4.1 Key considerations in building health workforce for UHC 
Building and maintaining a workforce fit to support UHC requires the development and sustaining of a long-term HRH agendainformed by the labour market.The challenge isto facilitate a well-informed dialogue with a sufficient range of stakeholders[34, 35]; maintaining a focus on the health workforce to support the long-term health plans, whilst appreciatingshorter-term needs of some HRH stakeholders;and whilst navigating an ever-changing environment(as in the study countries) such as decentralisation, pandemics and political transitions, civil unrest[36].Key to this process are:

- the leadership and accountability that recognises the health workforce as essential to achieving UHC

- robust and transparentmechanisms that promote political and social accountability and responsibility for performance and results/health workforce outcomes

- well informed stakeholders and decision makersthrough provision of good HRH information and the kind of 'HRH literacy'that enables them to plan for and understand changing health workforce characteristics

- a unified approach to coordination of stakeholders who support the timely development and oversight of an appropriate HRH strategysubsequently implementedand monitored[37] by an HRH unit (or equivalent organising structure).

\subsection{HRH coordination mechanisms}

The study identified numerous coordination mechanisms which may be fit for their specific purposes, but to support the HRH long-term agendathey need to be sustained and inclusive of a wide range of stakeholder interests[38] including those of the private sector and civil society. Task-oriented groups can be helpful, but they should be integrated into the wider coordination mechanism. The coordination mechanisms need to be seen as credible,so stakeholdersperceivea benefit or value in participation. Credibilityis enhanced by organisational support and the generation and availability of timely HRHdata. This can be achieved by various means, such asSudan's HRH observatory, though there are few functioning observatories in the African region. There is a need for coordination mechanisms to be owned and driven by the $\mathrm{MoH}$ and not reliant on externalfunding as this jeopardisessustainability.

\subsection{HRH units}

We found no evidence that a single HRH unit is essential, but there should be astructureto provide the necessary technical leadership and coordinate the development of HRH strategy and theimplementation of HRH activities. This is more complex, as in all study countries, when the management of health sector employees is spread across several government departments[39].The absence of a distinct HRH unit may explain the leadership of the employee adjustment process in Nepal byanother department in the MoHP, but even well-established HRH units may be side-linedregarding important $\mathrm{HRH}$ initiatives [40]. Coordination of HRH activities becomes yet more complex with the introduction of decentralised management structures. The speed of decentralisation may be unpredictable[32], but in Sudan this appeared to have been adequately planned for.There is a serious absence of expertise specific to managing the complexities of the health workforce.Surveys in Africa and 
South-East Asia report on small numbers of 'technical' or 'professional' staff[11, 28], but it is unclear if they have HRH expertise. However, much of this specialised knowledge - or 'HRH literacy' - can only really be learned on the job. The high level of turnover in $\mathrm{HRH}$ units makes this difficult in many countries that second 'common services' staff to HRH positions, whose tenure is short-lived. Filling theses skills gaps with time-limited consultants does not build the capacity needed[8]. A major input for HRH management is data, especially for workforce planning and monitoring and evaluation. Much donor support has been provided to developstand-alone information system, but this is often unsustainable.Further investigation of the Indonesian example of data sharing would be useful.

\subsection{Future actions}

This study has revealed many problems with HRH governance, but more information is needed. However, findings will be specific to each country context and the situation will constantly be changing. One approach could be for concerned individuals or groupspossibly, with assistance from local research groupsto document for themselves -guided by areas covered by this paper - a) the current state of HRH coordination mechanisms and their effectiveness, and $b$ ) thestructures and processes and their effectivenessfor implementation of HRH activities. Mapping the HR functions would help with the latter activity. The need for an effective HRH strategy based on a long-termvision that is actually implementedcouldresult from these actions. The Global HRH strategy[3] provides guidance on appropriate actions to strengthen these areas of $\mathrm{HRH}$ governance.This, in turn, would strengthen $\mathrm{HRH}$ literacy amongst stakeholders at all levels. With such a locally owned approach in place, donorscould be approached to provide assistance as needed. Documentation of this whole process would facilitate learning and benefit other countries.

\subsection{Strengths and limitations of the study}

As intended, this study has investigated $\mathrm{HRH}$ coordination and $\mathrm{HRH}$ units in greater depth than the NHWA reporting and the more detailed surveys from several WHO regions $[10,11,28]$. In addition, it has identified important tangential issues - such as the HRH strategy and the interdependence of $\mathrm{HRH}$ coordination mechanisms and HRH units - which are central to effective HRH governance. Nevertheless, there were limits on the time-frame, the number of interviews (which had to be carried out online) and available country-specific documentation. These challenges resulted in some loss of detail - especially the nuances of the politics of $\mathrm{HRH}$ - and limited the degree of triangulation possible.

\section{Conclusions}

The Global HRH strategy provides a useful stimulus to strengthen HRH governance through actions to coordinate HRH stakeholders and structures to develop and monitor HRH policies and plans. Reporting on these activities through the NHWA encourages implementation against the two milestones concerned. However, deeper understanding of the ways these mechanisms and structures operate is essential for enhancing their contribution to HRH governance and ultimately the HW contribution of achieving health goals. Thispaper, which provides some lessons, takes a first step in this direction. 


\section{Abbreviations}

AFRO African Regional Office (WHO)

DHRMD Directorate of human resource management and development $(\mathrm{MoH}, \mathrm{Malawi})$

DHRMD Department of human resource management and development (OPC, Malawi)

DoHS Department of Health Services (Nepal)

EMRO Eastern Mediterranean Regional Office (WHO)

FMoH Federal Ministry of Health (Sudan)

GLO Global (Respondent)

HRH Human resources for health

HRM Human resources management

HW Health Workforce

LSTM Liverpool School of Tropical Medicine

MoH Ministry of Health (Malawi)

MoHP Ministry for Health and Population (Nepal)

MWI Malawi (Respondent)

NCHC National Council for Healthcare Coordination (Sudan)

NHC National HRH Committee (Sudan)

NHRHO National Human Resources for Health Observatory (Sudan)

NHWA National Health Workforce Accounts

NPL Nepal (Respondent)

SEARO South-East Asian Regional Office (WHO)

SDN Sudan (Respondent)

ToR Terms of Reference

TWG Technical Working Group 
UHC Universal Health Coverage

WHO World Health Organization

\section{Declarations}

\section{Ethics approval and consent to participate:}

We received ethical approval from the Research Ethics Committee at Liverpool School of Tropical Medicine (21/055). Rigorous informed consent processes and mechanisms to assure confidentiality in data collection, analysis and storage were followed.

Consent for publication: Not applicable

Availability of data and materials: The datasets generated and/or analysed during the current study are not publicly available due confidentiality and ethical restrictions but are available from the corresponding author on reasonable request.

Competing interests: the authors declare that they have no competing priorities.

Funding: This study is funded by the World Health Organization.

\section{Authors' contributions:}

$\mathrm{TM}, \mathrm{MC}, \mathrm{KO}$ and JR conceptualised and designed the study, developed the data collection tools, collected the empirical data, analysed it and drafted the manuscript. TM, MC, KO, JR and WM reviewed the literature and conducted its qualitative analysis. DN, EB, FB, SB and SR critically reviewed the analysis and manuscript. All authors read and approved the final manuscript.

\section{Acknowledgements:}

Special gratitude goes to the participants in the three countries and other global participants for sharing their views honestly and for recognising the value of this research to the development of HRH agenda. Giorgio Cometto and Onyema Ajuebor, both from WHO, made technical contributions.

\section{References}

1. Lim MYH, Lin V: Governance in health workforce: how do we improve on the concept? A networkbased, stakeholder-driven approach. Hum Resour Health 2021, 19(1):1.

2. Afzal M, Cometto G, Rosskam E, Sheikh M: Global Health Workforce Alliance: increasing the momentum for health workforce development. Rev Peru Med Exp Salud Publica 2011, 28(2):298-307.

3. WHO: Global strategy on human resources for health: Workforce 2030. Geneva: World Health Organization; 2016. 
4. WHO: National health workforce accounts: a handbook. Geneva: World Health Organization; 2017.

5. Sales M, Kieny MP, Krech R, Etienne $C$ : Human resources for universal health coverage: from evidence to policy and action. Bull World Health Organ 2013, 91(11):798-798A.

6. Chhotray V, Stoker G: Governance in Public Administration and Political Science. In: Governance Theory and Practice 2009: 16-52.

7. Brinkerhoff DW, Bossert TJ: Health governance: concepts, experience, and programming options. Bethesda: Health Systems 2008, 20:20.

8. Fieno JV, Dambisya YM, George G, Benson K: A political economy analysis of human resources for health (HRH) in Africa. Hum Resour Health 2016, 14(1):44.

9. George A, Scott K, Govender V: A Health Policy and Systems Research Reader on Human Resources for Health. WHO; 2017.

10. Nyoni J, Gedik FG: Health workforce governance and leadership capacity in the African Region: review of human resources for health units in the ministries of health Human Resources for Health Observer 2012, (Issue 9).

11. Cometto G, Nartey E, Zapata T, Kanda M, Md Y, Narayan K, Pritasari K, Irufa A, Lamichhane R, De Silva $D$ et al: Analysing public sector institutional capacity for health workforce governance in the South-East Asia region of WHO. Hum Resour Health 2019, 17(1):43.

12. Cometto G, Nartey E, Zapata T, Kanda M, Md Y, Narayan K, Pritasari K, Irufa A, Lamichhane R, De Silva D: Analysing public sector institutional capacity for health workforce governance in the SouthEast Asia region of WHO. Hum Resour Health 2019, 17(1):43.

13. Barbazza E, Langins M, Kluge H, Tello J: Health workforce governance: Processes, tools and actors towards a competent workforce for integrated health services delivery. Health Policy 2015, 119(12):1645-1654.

14. Buse K, Walt G: Aid coordination for health sector reform: a conceptual framework for analysis and assessment. Health Policy 1996, 38(3):173-187.

15. Martiniuk A, Colbran R, Ramsden R, Karlson D, O'Callaghan E, Lowe E, Edwards M, Bagnulo S, Rothnie I, Hardaker $L$ et al: Hypothesis: improving literacy about health workforce will improve rural health workforce recruitment, retention and capability. Hum Resour Health 2019, 17(1):105.

16. Global Health Workforce Alliance: The Kampala declaration and agenda for global action. Geneva: WHO; 2008.

17. WHO: Health Workforce Support and Safeguards List. 2021.

18. National health Workforce Accounts portal https://apps.who.int/nhwaportal/Home/Index [https://apps.who.int/nhwaportal/Home/Index ]

19. Ministry of Health and Population [Malawi]: Human Resources for Health Strategic Plan, 2018-2022 2018.

20. Federal Ministry of Health: System of health accounts report. Khartoum Federal Ministry of Health; 2018. 
21. Chen L, Evans T, Anand S, Boufford JI, Brown H, Chowdhury M, Cueto M, Dare L, Dussault G, Elzinga GJTL: Human resources for health: overcoming the crisis. 2004, 364(9449):1984-1990.

22. Ritchie J, Spencer L, O'Connor W: Carrying out qualitative analysis. In: Qualitative research practice: a guide for social science students and researchers. Edited by Ritchie J, Lewis J. London: Sage; 2003.

23. WHO Regional Office for South-East Asia: Decade for health workforce strengthening in the SouthEast Asia Region 2015-2024; Mid-term review of progress, 2020. WHO. Regional Office for SouthEast Asia.; 2020.

24. MoHP [Nepal]: Nepal Health Sector Programme-II (NHSP-II) MTR Report. Final Report. . Kathmandu: Ministry of Health and Population; 2013.

25. Hazarika I: Health workforce governance: key to the delivery of people-centred care. International journal of healthcare management 2021, 14(2):358-362.

26. Van Ryneveld M, Schneider H, Lehmann U: Looking back to look forward: a review of human resources for health governance in South Africa from 1994 to 2018. Hum Resour Health 2020, 18(1):92.

27. World Health Organization: The African regional framework for the implementation of the global strategy on human resources for health: workforce 2030. 2020.

28. WHO Regional Office for Africa: The state of the health workforce in the WHO African Region, Brazaville: WHO Regional Office for Africa; 2021.

29. WHO: Decade for health workforce strengthening in the South-East Asia Region 2015-2024; Midterm review of progress, 2020. WHO Regional Office for South East Asia; 2020.

30. Martineau T, Caffrey M: Mapping the human resource functions across the Ministry of Health and Population and selected external government ministries, departments and agencies. Ministry of Health and Population (Nepal/NHSSP); 2013.

31. Bay F: An Analysis of Health Workforce Coordination Mechanisms and Structures in Low- and Middle- Income Countries. Liverpool School of Tropical Medicine UK; 2020.

32. Qian Y, Yan F, Wang W, Clancy S, Akkhavong K, Vonglokham M, Outhensackda S, Østbye T: Challenges for strengthening the health workforce in the Lao People's Democratic Republic: perspectives from key stakeholders. Hum Resour Health 2016, 14(1):72.

33. Federal Ministry of Health: National Human Resources for Health Strategic Plan for Sudan 20122016: Government of Sudan; 2012.

34. Working for health and growth: investing in the health workforce. Report of the High-Level Commission on Health Employment and Economic Growth. [http://www.who.int/hrh/comheeg/reports/en/]

35. Adeloye D, David RA, Olaogun AA, Auta A, Adesokan A, Gadanya M, Opele JK, Owagbemi O, Iseolorunkanmi A: Health workforce and governance: the crisis in Nigeria. Hum Resour Health 2017, 15(1):32. 
36. Russo G, Pavignani E, Guerreiro CS, Neves C: Can we halt health workforce deterioration in failed states? Insights from Guinea-Bissau on the nature, persistence and evolution of its HRH crisis. Hum Resour Health 2017, 15(1):12.

37. Buchan J: What difference does ("good") HRM make? Hum Resour Health 2004, 2(1):6.

38. Global Health Workforce Alliance: Country Coordlnatlon and Facllitatlon (CCF): principles and process. Undated.

39. Dieleman M, Hilhorst T: Governance and human resources for health. Hum Resour Healt 2011, 9(1):1-3.

40. Bertone MP, Samai M, Edem-Hotah J, Witter S: A window of opportunity for reform in post-conflict settings? The case of Human Resources for Health policies in Sierra Leone, 2002-2012. Confl Health 2014, 8:11.

41. Ministry of Health and Population [Government of Nepal]: Unofficial translation New Organizational Structure. Terms of Reference Undated. 